\title{
An Investigation into the Integration of Building Information Modeling with Pre-Construction Industry in the Developed Countries and Iran
}

\author{
Javad Majrouhi Sardroud ${ }^{1}, \underline{\text { Hamid Mehranpour }}^{2}$ and Abolfazl Arzanloo $^{3}$ \\ 1 Central Tehran Branch, Islamic Azad University, Iran, j.majrouhi@iauctb.ac.ir \\ 2 Central Tehran Branch, Islamic Azad University, Iran, (corresponding author), \\ Hamid.mehranpour@yahoo.com, \\ 3 Central Tehran Branch, Islamic Azad University, Iran, abolfazl.arzanloo@gmail.com
}

\begin{abstract}
Modern methods of construction buildings to improve the quality, reduce the time and cost, and increase their productivity have always been desirable for architectural, civil and construction engineers. In the 21st century, any evolution in technology was achieved with advancement in computer science. Building information modeling is actually a simulated multidimensional model related to building geometry, spatial relationships, geographic information, the amount and properties of all building components, and their intelligent communication with each other. This technology is a new approach to building design, implementation and management at the same time with great quality and coordination. Now days with the advancements in digital architecture, prefabrication and all kinds of building design optimization, it can be seen the growing use of building information modeling system in the construction industry. For this reason, building information modeling can have a significant effect on pre-fabrication. Also, by examining the building model, planning to install prefabricated components of the building and identifying executive interfaces will also be present. This paper examines the advantages and disadvantages of building information modeling, as well as the need for this type of software for the construction industry in the world and Iran.
\end{abstract}

(c) 2020 The Authors. Published by Budapest University of Technology and Economics \& Diamond Congress Ltd Peer-review under responsibility of the Scientific Committee of the Creative Construction Conference 2020.

Keywords: building information modeling, prefabrication industry, modern methods, construction industry

\section{Introduction}

The modeling of building information: in the last decade, building information modeling (BIM) is noticed significantly that points to the executive problems in building industry (ASHRAE,2009 \& Eastman, 2011). The modeling of building information includes real building information and is not just two _dimensional drawn plans of building that is drawn commonly by CAD software (Becerik-Gerber, 2009\& Krygiel, 2008). The complete description of BIM: a three dimensional simulated model consist of parametric elements that every element has special detailed concepts and includes demanded information of architecture and structure concepts and how they are made and its price and purchase and installation date, that information is being implemented in model by all the project stakeholders while model designing. This model is demonstrated as a four, five and multi dimension model regard to the cost and time information. This is a remarkable help for correct understanding of work by small contractors and is transferred the expectation of designers and engineers (Golabchi, 2016). these problems are associated with the relatively slow adoption and integration of advanced information technologies and industrialization principles such as mechanization, automation, robotics, standardization, modularization, and information- driven 
construction. Prefabrication Housing Production (PHP), asan innovative solution in the construction industry, uses the principles of industrialization in the lifecycle of construction projects, includingdesign, manufacturing, transportation, on-site assembly, maintenance, and deconstruction stages(Li et al.).

\section{Generation}

The prior reasons for BIM generation are the existence of several problems in traditional system of plan presentation that its usage lead to fix these problems and the workability improvement in construction process (NIBS, 2007). BIM process is not a progress or a development of work process, it is a fundamental evolution in work infrastructure (Azhar et al, 2008a,2008b\& Beck, 2011). For the first time, BIM was defined like this: it's a series of processes that includes production and processing of digital profiles to describe spaces and performances. The result of building information modeling, help practitioners from the first stages of brainstorm in design to construction stages and at last the operation along whole the project (Golabchi, 2016). National standard building information modeling forums NBIMS, defined BIM as: a complex process in relationship of planning, designing, construction, performance and facility management through a standard information model that is readable by devices and new and old programs, that includes all appropriate produced or collected information in relationship with that facilities in usable opportunities from all stakeholders in the cycle of project (NBIMS, 2007). BIM concept in BIM handbook is this: new modeling technology and the related series of processes for production, relationship and analyzing the building models (Eastman, 2011\& EASTMAN,2012). The BIM concept includes the infrastructure of IT devices that integrates design into one. Also, supports the construction and building operation. (Merschbrock,2012). BIM is it's a series of processes that includes production and processing of digital profiles to describe spaces and performances. The result of building information modeling, help practitioners from the first stages of brainstorm in design to the construction stages and at last operation along whole the project. (Lloyd,2009\& Golabchi,2016). the available tools in BIM are divided to three separated parts:

$$
\begin{array}{ll}
\text { - } & \text { 3D - Modelers } \\
\text { - } & \text { Viewers/ surface modelers } \\
\text { - } & \text { Analyzers }
\end{array}
$$

Three-dimension modeling: it's a real tool for BIM that the parametric things with adequate details are used imaginary in it through solid materials to build a structure.

Viewers/ surface modelers: all the aspects of project don't need to have the same details. Although the financing provider may like to see how the building would be like and for this you just need to a superficial modeling that all the objects are empty in it. The only thing that is defined, is in work surface and is used to demonstrate the idea. This demonstrates the contracts in first stage and is so valuable.
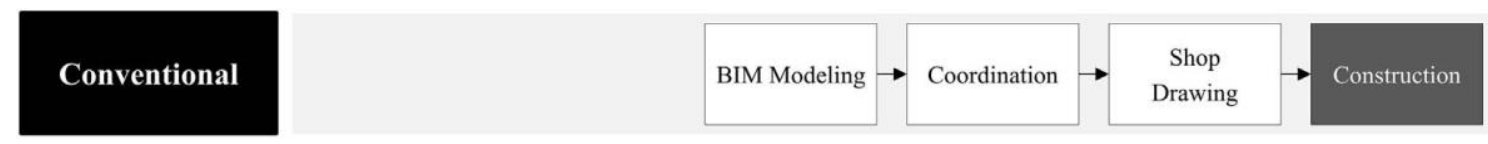

Figure1. Design and coordination process of the conventional method[37]

Analyzers: normally it's a supplementary software that plays the role of the main BIM tool. It means that it can receive information from three-dimension model and estimates and analyzes the energy efficiency and how to lightening in different seasons accomplished by so many things. While so many companies are active in the BIM area and the production of software, like any industry each has a market share that as a sample, the following chart demonstrates the download rate of BIM different companies in UK that Bently BIM Suite, Vector works, IFC, Archi CAD, Revit are the main providers of BIM services (Bimtalk,2013). In figure 1 the percentage of market share is presented by each BIM producer companies: 


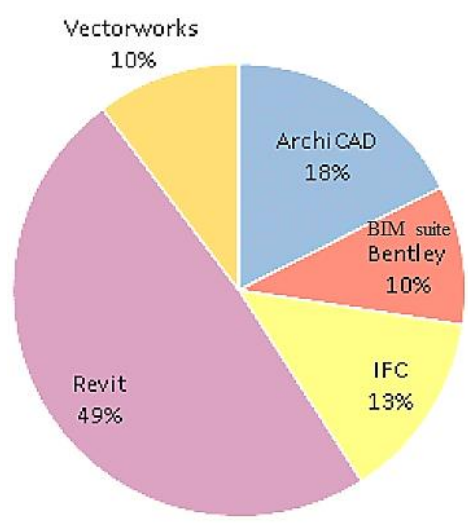

Figure 2. The percentage of market share is presented by each BIM producer companies

Many researchers had identified the advantages ofapplying prefabrication (OST, 2001\&, YH,1997). Seven benefits of applyingprefabrication are used for conducting the survey: (i) frozen design at the early design for better adoption of prefabrication; (ii) better supervision on improving the quality of prefabricated products; (iii) reduce overall construction costs; (iv) shorten construction time; (v) environmental performance improved for waste minimization; (vi) integrity on the building design and construction; and (vii) aesthetic issues on the building.

\section{The review of other countries' studies}

A study about building information modeling is done in developed countries in the field of building industry in north America (Canada and America) and East Asia (South Korea, Hong Kong and japan). The following cases can be understood:

\subsection{Standardization}

This study shows that many of countries like America and UK have stablished and passed required standards in the field of BIM that makes it not only available as a method, but also makes it obligated in some cases (Mc Graw Hill Construction, 2014).

Some available standards in the field of building information modeling, could be described as fallow:

The standard of architecture, engineering and construction industry: this standard made available a general standard to use BIM and a separated standard for the users of Revit and BIM Suite Bentley specially for AEC UK based on BS 1192. This standard has been published in the early summer of 2012 (Hergunsel,2011\& Chair,2012).

American National Standards: BIM National Standard has been stablished by American Intelligent Building Association that the firs version of it was published in 2007 and from 2012, the second version of it was published and the third version of it is being edited. This very great document looks useful and is used in COBIE project (Han,2008\& NBIMS,2007).

Hong Kong Standard: BIM Hong Kong Standard has described the BIM goals and detail levels. (HKIBIM,2007)

American Army Retirement Building and Facilities Management Standard: the department of the affairs of American Army Retirement Building and Facilities Management has been provided a complete BIM guideline from the view of employer. This standard has been edited in 2010. (El Dado,2011\& CFM,2010)

The executive program of the university of Pennsylvania: this program has been used as a foundation for BIM programming. Now, the second version of this standard which has been published in 2010, is used. (Engineering, P. S., 2010) the national guide for Australian digital modeling: this standard has been published by cooperative research center for innovation in construction in 2009. (Austoralia,2009\& HKIBIM, 2007) 
New Zealand and Australian Revit standard: this standard has focused specially on Revit. The third version of this standard has been available from 2012.

\subsection{The published articles around building information}

According to researches done with the end of 2015, The United States is remarkably pioneer compared to other countries in the world in the production of scientific documents in the field of building information modeling. This rate is $30 \%$ of all articles. The Scandinavian countries with the rate of 17.59 totally have the second rank in the production of science in this field in the world. (BuildingSMART, 2010, Carneiro, 2012). This issue is combines by a chart in 2012 by Carneiro et al and with further investigations by 2015 that has been updated and this ranking has been correct yet. It should be said that this much difference, shown in the following chart, can be due to differences in operating systems, more appreciation for new technology, the existence of universities and educational centers with special management tendencies and building information modeling. presents the distribution of the 65 publications by the country/region and the prefabrication production structures of these publications. United States, Hong Kong, United Kingdom, and Israel are the top four countries or regions, in terms of publications on BIM-PHP.

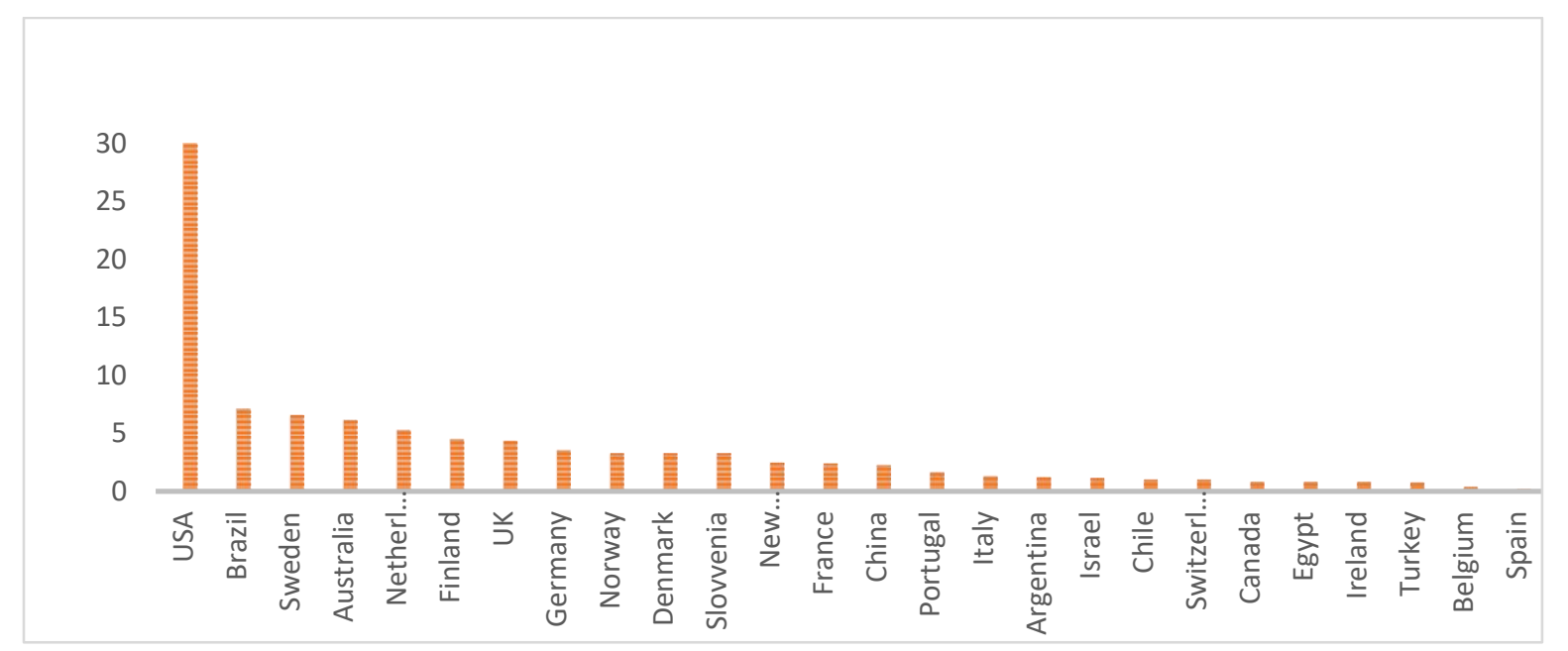

Figure 3. The chart of published articles in the field of building information modeling in different countries (Carneiro, 2012)

At last, the overview of the theories and other studies of researchers is presented in table 1: Table 1. The theories and other studies of researchers

\begin{tabular}{|c|c|c|c|c|c|c|c|}
\hline & 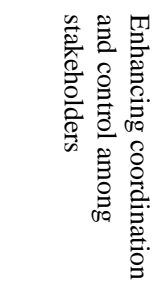 & 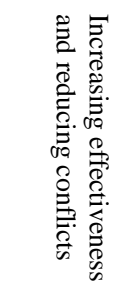 & 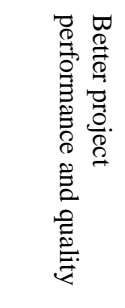 & 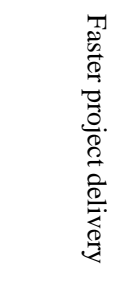 & $\begin{array}{l}\sum_{0} \\
\underline{w} \\
\overrightarrow{0} \\
\overrightarrow{0} \\
\stackrel{0}{0} \\
\stackrel{0}{0}\end{array}$ & 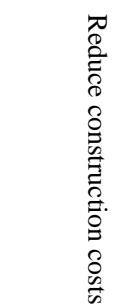 & 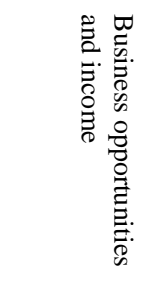 \\
\hline (Beck, 2011) & $*$ & & & $*$ & $*$ & * & \\
\hline (Hergunsel, 2011) & $*$ & $*$ & & $*$ & $*$ & $*$ & $*$ \\
\hline (Radriguez, 2011) & $*$ & $*$ & & $*$ & $*$ & $*$ & $*$ \\
\hline (El Dado, 2011) & $*$ & $*$ & $*$ & $*$ & & * & * \\
\hline (Buiding Smart, 2010) & & & & $*$ & $*$ & $*$ & $*$ \\
\hline (Giel and Issa, 2010) & & $*$ & $*$ & $*$ & & & \\
\hline Ashrai,2009) & $*$ & $*$ & $*$ & $*$ & $*$ & & $*$ \\
\hline $\begin{array}{lll}\text { Becerik- } & \text { Gerber } & \text { and } \\
\text { Rice,2009) } & & \\
\end{array}$ & & & & $*$ & $*$ & $*$ & \\
\hline $\begin{array}{l}\text { (Azhar, Hein and Sketo, } \\
\text { 2009) }\end{array}$ & $*$ & & $*$ & $*$ & & & $*$ \\
\hline (Hardin,2009) & $*$ & $*$ & * & $*$ & & & * \\
\hline (underwood and Isidog, 2009) & $*$ & $*$ & $*$ & $*$ & * & * & * \\
\hline (Han and Damaian, 2008) & & & $*$ & $*$ & * & $*$ & \\
\hline (Herley,2008) & & & & $*$ & $*$ & $*$ & \\
\hline
\end{tabular}


In the other view and according to the expressions and definitions of the building information modeling in table 2 and 3, the probable advantages and disadvantages and the opportunities and threats of implementation of building information modeling are presented in this analytical tables.

Table 2. The advantages and disadvantages of building information modeling

\begin{tabular}{|c|c|}
\hline Weak points & Strength points \\
\hline $\begin{array}{l}\text { Traditional work processes and low acceptance of new technologies } \\
\text { in construction projects (mainly in third world countries) }\end{array}$ & $\begin{array}{l}\text { Increasing productivity and helping to get out of the recession in the } \\
\text { construction industry }\end{array}$ \\
\hline $\begin{array}{l}\text { Need to train employees and beneficiaries in contracting } \\
\text { companies, consultants and employer agencies }\end{array}$ & $\begin{array}{l}\text { Decreasing the reworks and increasing the rate of projects } \\
\text { according to project delays }\end{array}$ \\
\hline \multirow{3}{*}{$\begin{array}{l}\text { Definition of building information modeling in some of the } \\
\text { companies that means } 3 \text { dimension design that was itself one of the } \\
\text { obstacles to its serious application. }\end{array}$} & $\begin{array}{l}\text { Facilitating the employer, contractor and consultant communication } \\
\text { and making quick decisions in times of change. }\end{array}$ \\
\hline & Reduction of office work and routine correspondence \\
\hline & $\begin{array}{l}\text { Ability to connect material vendors and suppliers to formulate the } \\
\text { required supply chain program }\end{array}$ \\
\hline
\end{tabular}

Table 3. The opportunities and threats of using the building information modeling

\begin{tabular}{|l|l|}
\hline Threats & Opportunities \\
\hline Lack of proper financial potential in the current situation & $\begin{array}{l}\text { Integrating information into construction projects to provide } \\
\text { materials, financial estimates, and even at the macro level strategic } \\
\text { planning to build the related industries required to deliver accurate } \\
\text { estimates and reduce delays will strengthen active construction } \\
\text { companies and reduce losses. }\end{array}$ \\
$\begin{array}{l}\text { The absence of binding rules for specific projects that serve the } \\
\text { interests of companies in the direction of building information } \\
\text { modeling. }\end{array}$ & $\begin{array}{l}\text { Reduce the environmental impact of construction projects with the } \\
\text { help of energy, light analysis, and help achieve high environmental } \\
\text { policies. }\end{array}$ \\
$\begin{array}{l}\text { assuming the enactment of supporting laws } \\
\text { a lack of familiarity among executives and decision makers } \\
\text { display and comparing it with 3D MAX ... }\end{array}$ & $\begin{array}{l}\text { The potential to emerge as a start-up for small companies that } \\
\text { specialize in implementing this theme in projects. }\end{array}$ \\
$\begin{array}{l}\text { Lack of strong communication infrastructure for wide web } \\
\text { interactions (mainly in third world countries) }\end{array}$ &
\end{tabular}

\subsection{An overview of research in Iran and research needs}

The study and investigation of building information modeling that has been done in Iran is in this way that since late 2012 in Iran, building information modeling has been considered by researchers as a new field for research. A number of qualitative studies are needed to disseminate relevant knowledge and understanding of the effects that can be said on building information modeling in most of the areas except issues such as project delivery integration, maintenance, inter-software information exchange and process modification, Appropriate qualitative studies have been conducted in Iran, and now needs practical application with quantitative modeling and case studies to gain a deep understanding of the effects of applying this technology to the various aspects of the construction industry, a research vacuum being observed, and the only case that can attempt to implement building information modeling As a case study, is 3D modeling of the Carson 4 bridge used after the design and construction of the technology, which did not produce very tangible results and did not show the value that could be attributed to the technology in the project. Reasons for the construction industry's disapproval of the introduction of technology can be known due to the current recession, the existence of experimental contractors and traditional construction, the need to apply building information modeling technology to changes in rules, standards, working methods, project communications, definitions of work processes based on new philosophies (such as lean manufacturing) that without these changes it would not be possible to implement them fully, and the effect of building information modeling would be shown as a three-dimensional demonstration model of projects (Underwood, 2009\& Arianhasal, 2016). 
Arian Carmel and Majruhi Sardrood has evaluated and researched the impact of using this technology in reducing pre-construction problems by investigating the pre-construction problems and taking into account the unique features of building information modeling technology (Arianhasal, 2016).

\subsection{Pre-construction}

Prefabrication of building components as a degree of industrial manufacturing is a new method of construction that is widely used today in developed countries, reducing construction costs due to the mechanization of the manufacturing process, reducing the manpower involved, significantly reduced manufacturing time, increased quality and durability of structures due to factory-made components, reduced consumables and thus less environmental degradation are industry characteristics. Most importantly, the system is environmentally friendly and uses Resources are also significant during construction and productivity, and energy and space consumption, as well as pollution generation. It does not exceed environmental capacity and considers intergenerational justice (NBIMS,2007, Rodriguez, 2011 \& Sacks,2012).

Prefabrication in building industry, design and Manufacturing of prefabricated and complex concrete and metal structures, prefabricated walls, prefabricated electrical and mechanical equipment are examples of applications of this technology. Qualitative and quantitative developments in housing construction and appropriate living space are correlated with economic, social, and cultural developments in different regions, and are not inseparable. In addition, taste of art and technology, have been some of effective elements in Qualitative and quantitative production of housing and according to papulation growth and Increasing need for housing and immigration to the cities, deep and fundamental developments are generated in this industry. In the meantime, a new construction method Entitled Pre-construction, quickly established itself in the building industry and its scope has become so widespread that in some countries it is now more than $70 \%$ of construction using this method.

\subsection{Generation}

Prefabrication in building industry has been considered named Prestressed Concrete in 1886 in United State for the first time and its defects were eliminated after half a century. Although Prefabrication in building industry began by Egyptian Pyramids, Roman and Greek temples and Sassanid and Achaemenid palaces, but its industrial development has been after the industrial revolution and the invention of concrete and steel and the emergence of new construction techniques. The first concrete and preconstruction sites were established in the United Kingdom, from which the construction of schools by the CLASP, SCOLLA and SEAC consortia can be noted. In general, the pre-construction development of the construction industry in Europe after World War II was the focus of reconstruction programs in the affected areas. The use of this industry in some countries has been such that it has completely replaced the traditional construction industry. Its years that this new method is used in European countries and development countries and has strengthened its position by technical tests and acceptable experiences. Prefabrication elements in addition to residential buildings, are used in the construction of industrial halls, bridges and other stuffs. Prefabricated construction industries and sophisticated systems create a tremendous speed in the implementation of construction programs. 


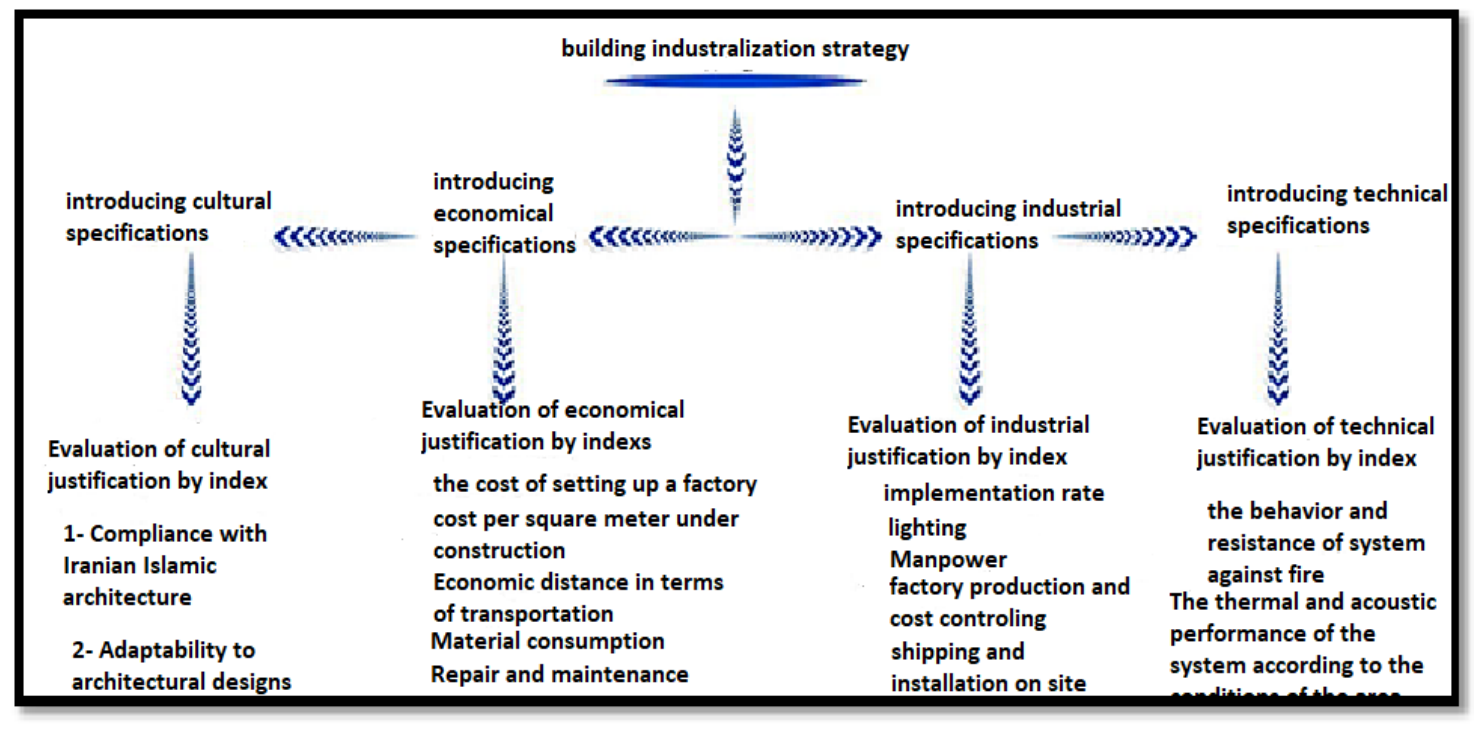

Figure 4. The total view of building industrial strategy

With regard to the history of pre-construction in the building industry, it should be noted that building production or domestic construction is carried out in two ways:traditional way.

\subsection{Industrial method}

The traditional construction includes common methods of construction in the country in reinforced concrete buildings that includes excavation and execution of foundations, columns, beams, ceilings, molding and concrete casting that every stage, depended on different causes need too much time and about buildings with steel frame, excavating and executing the foundation and setting up the skeleton and welding, itself takes a long time.

In addition to the above issues, how to implement concrete and steel structures in the workshop has its own problems. In concrete structures, the most important issue is the construction of concrete and its mixing design, and the manner in which concrete is poured and processed. In the case of steel frame, the welding of joints is particularly important which is done by semi-skilled workers. Industrial methods in Iran mainly consist of concrete structures and are discussed in three cases:

Avoiding Delays Due to Unfavorable Weather Conditions: Manufacturing of prefabricated parts is often confined, making it possible to perform work in any adverse weather conditions, which is one of the reasons for this type of construction in cold areas.

Increasing the speed of assembly on site: Although the production and manufacture of components using new technologies accelerated the manufacturing and processing of concrete, it can save more time on assembly on site.

Before using BIM and demanded software, prefabricated elements are coordinated and fragmented through CAD, that there is limitation in the complete imagination of the construction method of these 3 dimension structures, but after the appearance of BIM and the Software such as Tekla Structures that enables it to configure loading, partial mapping, assembly, and even in the case of a steel structure, also provides clipping program for the CNC machine. this procedure has changed in general and can be said to give high dynamics to the design and construction phases of these structures.

The prefabrication stages in building industry according BIM are as follows:

Total design of building by design team that is done like the common buildings and is sent for the prefabricated specialists to provide the prefabricating plan. 
Then, the structural elements are divided to Fabricable pieces and portable, of course, with considering the traffic restrictions.

Actually, the structure that is prefabricated, is referred to design unit to make final decision and to provide the instruments and demanded materials.

Prefabricated pieces are assembled and produced on the assembly line based on instructions usually prepared according to the project execution schedule

After manufacturing the pieces, they Prefabricated pieces are assembled and produced on the assembly line based on instructions usually prepared according to the project execution schedule packaged and, counted and named and posted to the site according to schedule

Parts are installed on site

The conceptual framework also echoes the concept of industry 4.0 (Akanmu, 2015\& Yuan,2016) which is considered as an emerging trend for achieving a timely interaction between the virtual platform and the physical environment through information technologies such as cyber-physical systems (CPS), the internet of things, cloud computing and cognitive computing.

\section{Conclusion}

The building information modeling is one of the most promising developments in the construction industry. Through this technology, one or several imaginary digital models are produced with high accurate and help to the design process and the combination the BIM with prefabrication provides this special opportunity to the contractors that prepare pre-fabrication methods including production and installation and equipment needed before the beginning the project. Whole the executive team including the main contractors, small contractors and builders in each production and installation section can work together in every part of production and installation through the imaginary simulation of the manufacturing process to practice the execution sequences (production and installation), locating production sites, depots, towers, elevators and project site management and assessing the impact of their decisions prior to implementation.

\section{References}

[1] ASHRAE, An Introduction to Building Information Modeling (BIM), Atlanta: American Society of Heating Refrigerating and AirConditioning Engineers, Inc. pp. 1319-1380, 2009.

[2] Eastman, C., Teicholz, P., Sacks, R., Liston, K.,. BIM Handbook, A guide to Building Information modeling for Owners, Managers, Designers,Enginners and Contractor, New Jersey: John Wiley \& Sons.

[3] Becerik-Gerber, B., \& Rice, S. August 31. The Value of Building Information Modeling: Can We Measure the ROI of BIM. Retrieved January 23, 2012, from AECbytes: http://aecbytes.com/viewpoint/2009/issue_47.html.

[4] Krygiel, E., Nies, B., Green BIM: Successful Sustainable Design with Building Information Modeling, Indiana: John Wiley \& Sons.

[5] Mahmood Golabchi, Alireza Golabchi, Esmat Norzai, Kobra Faroni JafariBuilding Information Modeling, University of Tehran Publications, 2016.

[6] NIBS,2007, Introduction to: National BIM Standard Version 1, Part 1-Overview, Principles, \& Methodologies. National Institute of Building Science (NIBS), Facilities Information Council (FIC) National BIM Standard https://doi.org/10.1080/17452007.2012.659506

[7] Azhar, S., Hein, M., \& Sketo, B. Building Information Modeling (BIM): Benefits, Risks and Challenges. Alabama: McWhorter School of Building Sciences:Auburn University.2008.

[8] AZHAR, S., NADEEM, A., MOK, J. \& LEUNG,B. Building Information Modeling (BIM): A new paradigm for visual interactive modeling and simulation for construction projects. Proc., First International Conference on Construction in Developing Countries,, 2008. . pp 222-235.

[9] Beck, E. 2011. BIM Well With Others: The benefits of building information modeling are more promise than reality.. Retrieved January 23, from Architecture: The Magazine of The American Institute of Architects: http://www.architectmagazine.com/bim/bim-well-withothers.aspx. 2012.

[10] NBIMS. National Building Information Modelling Standards: Overview. United States: National Institute of Building Science., 2007. https://doi.org/10.1016/j.autcon.2008.10.003

[11] MCGraw Hill Construction, Business Value of BIM for Construction in Major Global Markets. In: Business Value of BIM for Construction in Major Global Markets. s.I.:MCgraw Hill, 2014.

[12] Merschbrock, C., Munkvold, B.EA Research Review on Building Information Modeling in Construction-An Area Ripe for IS Research. Communications of the Association for Information Systems: Vol. 31, Article 10, Available at: . 2012, http://aisel.aisnet.org/cais/vol31/iss1/10.

[13] Giel, B., \& Issa, R. R, Quantitative Benefits of Building Information Modeling Measured in Construction. Leicestershire: Loughborough University. 2010.

[14] EASTMAN, C., JEONG, Y.-S., SACKS, R. \& KANER, I, Exchange model and exchange object concepts for implementation of national BIM standards. Journal of Computing in Civil Engineering, 2112. 22, .32-25. https://doi.org/10.1061/ASCE0887-3801201024:125 
[15] Merschbrock, C., Munkvold, B.E., A Research Review on Building Information Modeling in Construction-An Area Ripe for IS Research. Communications of the Association for Information Systems: Vol. 31, Article 10,, 2012. Available at: http://aisel.aisnet.org/cais/vol31/iss $1 / 10$.

[16] Bimtalk, 2013. software_applications - BIMTalk. NBS 'National BIM Library. ,2009 . Available at: http://bimtalk.co.uk/software_applications [Accessed November 26, 2015].

[17] Mc Graw Hill Construction,.the business value of BIM for construction in major global markets, 2014

[18] Hergunsel, M. Benefits of Building Information Modeling for Construction Managers, Worcester Polytechnic Institute., 2011. https://digitalcommons.wpi.edu/etd-these.

[19] Chair, A... A unified standard for the Architectural, Engineering and Construction industry in the UK., 2012.

[20] Han, Y., \& Damian, P. Benefits and Barriers of Building Information Modelling. United Kingdom: Department of Civil and Building Engineering, Loughborough University, 2008. :https://dspace.lboro.ac.uk/2134/23773.

[21] Hardin, B. BIM and Construction Management: Proven Tools, Methods and Workflows. Indiana: Wiley Publishing Inc,, 2009.

[22] Hurley, A. K,November 11. Technology: Side Benefits of BIM. Retrieved January 23, 2012, from Architect - The Magazine of The American Institute of Architects: http://www.architectmagazine.com/bim/side-benefits-of-bim.aspx, . 2008.

[23] EI Dado, F. Building Information Modeling: Benefits, Obstacles, Adoption. LAP LAMBERT Academic Publishing, 2011.

[24] CFM, T. U. D. o. V. A. (. O. o. C. \&. F. M., The VA BIM Guide-Building Information Lifecycle Vision,, 2010.

[25] Engineering, P. S BIM Project Execution Planning Guide. [Online] Available at: http://bim.psu.edu/Project/resources/default.aspx, ., 2010.

[26] Austoralia, N. G. f. D. M. National Guidelines for Digital Modelling. ., 2009. [Online] Available at: http://www.constructioninnovation.info/images/pdfs/BIM_Guidelines_Book_191109_lores.pdf

[27] BuildingSMART. Investors Report - Building Information Modelling (BIM). UK, 2010.

[28] Carneiro, T. M., et al. Spread of BIM: a comparative analysis of scientific production in brazil and abroad, Annual Conference of the International Group for Lean Construction, 2012. http://www.repositorio.ufc.br/handle/riufc/5812

[29] Underwood, J., \& Isikdaq, U,Handbook of Research on Building Information Modeling and Construction Informatics. Information Science Publishing, . 2009.

[30] Siamak Arianhasal, Javad Marjouhi Sardrood, 2016. The Impact of Building Information Modeling on Reducing Pre-Construction Problems, First Conference and Third National Conference on Construction Management, Tehran, Iran. NCCPM03_188

[31] (NBIMS), 2007. Alan Edgar, Assoc. AIA, Chair, National BIM Standard Executive Committee,.

[32] Rodriguez, J. Building Information Modeling (BIM) Benefits. Retrieved January 23, 2012, from About.com Construction: http://construction.about.com/od/Technology/a/2011.,Building-Information-Modeling

[33] Sacks, R., Partouche, R. Empire State Building Project: Archetype of Mass Construction, Journal of Construction Engineering and Management, ., 2010, p. 702-710, https://doi.org/10.1061/(ASCE)CO.1943-7862.0000162

[34] X. Li, G.Q. Shen, P. Wu, H. Fan, H. Wu, Y. Teng, RBL-PHP. simulation of lean construction and information technologies for prefabrication housing production, J. Manag. Eng. 34 (2) 04017053, ,2017, https://doi.org/10.1061/(ASCE)ME.1943-5479.0000577.

[35] I.J. Ramaji, A.M. Memari. Product architecture model for multistory modular buildings, J. Constr. Eng. Manag. 142 (10) 04016047 , 2016, https://doi.org/10.1061/(ASCE)CO.1943-7862.0001159.

[36] Akanmu, C.J. Anumba. Cyber-physical systems integration of building informationmodels and the physical construction, Eng. Constr. Archit. Manag. 22 (5) (2015) 516-535, https://doi.org/10.1108/ECAM-07--0097.

[37] X. Yuan, C.J. Anumba, M.K. Parfitt. Cyber-physical systems for temporary structure monitoring,, 2016,Autom. Constr. 66 1-14, https://doi.org/10.1016/j.autcon. 2016.02.005.

[38] F.H. Abanda, J.H.M. Tah, F.K.T. Cheung, BIM in off-site manufacturing for buildings, J. Build. Eng. 14 (2017) 89-102, https://doi.org/10.1016/j.jobe.2017.10.002

[39] Ho OST. Construction waste management-a contractor's perspective. The Hong Kong Institute of Builders;, 2001, July, 8-11.

[40] Ting YH. The economic implications of subcontracting practice on building prefabrication. Automation in Construction;, 1997,6(3):16374. https://doi.org/10.1016/S0926-5805(97)00001-0 